\title{
Effect of chickpea (Cicer arietinum L.) varieties and weed management practices on quality parameters, nutrient content and uptake by crop and weed
}

\author{
SHIV CHANDRAKAR* ${ }^{*}$ AKANKSHA SHARMA ${ }^{1}$ AND DINESH KUMAR THAKUR ${ }^{2}$ \\ Department of Agronomy, N.M. College of Agriculture, Navsari Agricultural University, NAVSARI (GUJARAT) \\ INDIA (Email : shivchandrakar1512@gmail.com)
}

\begin{abstract}
A field experiment was carried out at the Navsari agricultural university, Navsari during 2011-2012 to study the effect of chickpea (Cicer arietinum L.) varieties and weed management practices on quality parameters, nutrient content and uptake by crop. The result indicated that significantly maximum protein content $(21.35 \%)$ and protein yield $\left(385 \mathrm{~kg} \mathrm{ha}^{-1}\right)$ as well as nutrient content in seed $\mathrm{N}(3.42 \%), \mathrm{P}(0.72 \%)$ and $\mathrm{K}(0.87 \%)$, in stover $\mathrm{N}(1.41 \%), \mathrm{P}(0.25 \%)$ and $\mathrm{K}(1.42 \%)$ and uptake of nutrient by seed $\mathrm{N}\left(61.65 \mathrm{~kg} \mathrm{ha}^{-1}\right), \mathrm{P}_{2} \mathrm{O}\left(13.06 \mathrm{~kg} \mathrm{ha}^{-1}\right)$ and $\mathrm{K}_{2} \mathrm{O}\left(15.76 \mathrm{~kg} \mathrm{ha}^{-1}\right)$ were recorded by treatment $\mathrm{W}_{2}$ (Weed free upto harvest- H.W. 20, 40 and 60 DAS) as compared to unweeded (control), respectively. All varieties of chickpea found equally suitable for cultivation.
\end{abstract}

Key Words : Chickpea, Quality parameters, Nutrient content, Uptake

View Point Article : Chandrakar, Shiv, Sharma, Akanksha and Thakur, Dinesh Kumar (2015). Effect of chickpea (Cicer arietinum L.) varieties and weed management practices on quality parameters, nutrient content and uptake by crop and weed. Internat. J. agric. Sci., 11 (2) : 217-220.

Article History : Received : 14.01.2015; Revised : 02.05.2015; Accepted : 16.05.2015

\footnotetext{
* Author for correspondence

${ }^{1}$ Department of Horticulture, Indira Gandhi Krishi Vishwavidyalaya, RAIPUR (C.G.) INDIA

${ }^{2}$ Department of Genetics and Plant Breeding, Indira Gandhi Krishi Vishwavidyalaya, RAIPUR (C.G.) INDIA
} 